\title{
Pressure Ulcers in Institutionalized Elderly People: Association of Sociodemographic and Clinical Characteristics and Risk Factors
}

\author{
Suellen Duarte de Oliveira Matos ${ }^{1}$, Iraktânia Vitorino Diniz ${ }^{1}$, Adriana Lira Rufino de Lucena ${ }^{1}$, \\ Smalyanna Sgren da Costa Andrade1, Karen Krystine Gonçalves de Brito', \\ Elizabeth Souza Silva de Aguiar', Emanuelle Malzac Freire de Santana1, \\ Mailson Marques de Sousa', Ana Paula Marques Andrade de Souza1, \\ Hemílio Fernandes Campos Coêlho², Mirian Alves da Silva1, Marta Miriam Lopes Costa1, \\ Maria Julia Guimarães Oliveira Soares ${ }^{1}$, Simone Helena dos Santos Oliveira1 \\ ${ }^{1}$ Graduate Program in Nursing, Universidade Federal da Paraíba, João Pessoa, Brazil \\ ${ }^{2}$ Departament of Statistics, Universidade Federal da Paraíba, Paraíba, Brazil \\ Email: suellen 321@hotmail.com
}

How to cite this paper: de Oliveira Matos, S.D., Diniz, I.V., de Lucena, A.L.R., da Costa Andrade, S.S., de Brito, K.K.G., de Aguiar, E.S.S., de Santana, E.M.F., de Sousa, M.M., de Souza, A.P.M.A., Coêlho, H.F.C., da Silva, M.A., Costa, M.M.L., Soares, M.J.G.O. and dos Santos Oliveira, S.H. (2017) Pressure Ulcers in Institutionalized Elderly People: Association of Sociodemographic and Clinical Characteristics and Risk Factors. Open Journal of Nursing, 7, 111-122.

http://dx.doi.org/10.4236/ojn.2017.71010

Received: December 29, 2016

Accepted: January 19, 2017

Published: January 22, 2017

Copyright $\odot 2017$ by authors and Scientific Research Publishing Inc. This work is licensed under the Creative Commons Attribution International License (CC BY 4.0).

http://creativecommons.org/licenses/by/4.0/

(c) $\underset{\mathrm{EY}}{\mathrm{B}}$ Open Access

\begin{abstract}
Objective: To evaluate the association of socio-demographic and clinical characteristics, and risk factors with occurrence of pressure ulcers in institutionalized elderly people. Method: This cross-sectional, analytical study, in quantitative approach, performed from the database analysis linked to the project "Pressure Ulcer in institutionalized elderly people: Association of incidence with the risk factors to functional and nutritional assessment" developed in six long-stay institutions for the elderly people in João Pessoa. Data were analyzed using the Statistical Package for Social Sciences (SPSS) version 20.0. Associations were made through chi square test and Odds Ratio. Results: The clinical conditions of significant associations with the occurrence of pressure ulcers were the variables neurological disorders $(\mathrm{p}=0.011)$ and visual impairment $(p=0.005)$. As for risk factors, the most important was fecal incontinence $(\mathrm{p}<0.001)$, urinary incontinence $(\mathrm{p}<0.001)$, cognitive impairment $(\mathrm{p}$ $=0.007)$ and physical limitation $(\mathrm{p}<0.001)$. The chance for the occurrence of injury was nine times higher for elderly people with physical limitations and about three times higher among those who use diapers. Conclusion: The analysis of the associations pointed out problems that require intervention in order to prevent health implications of the elderly people and to minimize the risk and occurrence of this injury.
\end{abstract}

\section{Keywords}

Elderly People, Institutions for the Elderly People, Pressure Ulcer, Health 
Profile, Risk Factors

\section{Introduction}

Population aging has attracted attention in the scientific community, as it represents the basis for reversing the Brazilian age pyramid. This transformation of the demographic profile implies increased demand for health services, social security sector and human resources to care for the elderly people.

With the natural aging process, there are several organic physiological, anatomical and functional changes, reflecting to the increase of chronic diseases, morbidity, and loss of functional, sensory, motor and metabolic capacity, taking the elderly person to a fragile condition. The situation of irreversible vulnerability promotes functional dependence of the individual, which becomes a cause for concern in family life.

However, it is the need for constant care that causes the search for institutionalization of elderly people for the absence of family, or abandonment, lack of financial resources or the imposition of the capitalist world that enslaves the time availability of the company, making it impossible to offer care [1].

This scenario contributes to increase in demand for places in Long Term Care Institutions (LTCI), formerly asylums. These constitute governmental or nongovernmental institutions are responsible for the care of dependent or independent elderly person [2] [3].

When considering the specific conditions of the elderly person, it is the LTCI which provides quality assistance to long-lived population, in order to provide maintenance and restoration of health and quality of life. Therefore, considering the decline in biological functions inherent to the aging process, the accesses to care by a qualified multidisciplinary team to work in gerontology have been shown as essential for the promotion of health and well-being of institutionalized elderly people [4] [5].

Although the ideal profile requires the presence of a multidisciplinary team in LTCI [6], experiences in these scenarios point to a reality in which health care is provided by nursing professionals in a very small number and elderly caregivers who are often without the required professional training, compromising the best directed care.

About the vulnerability of the elderly people to morbidities, studies cite the appearance of pressure ulcers (PU) as a cause of recurrent loss of health and as difficult injury control in institutionalized elderly population [7] [8]. Its development involves extrinsic and intrinsic factors, while physical mobility, decreased sensory perception and the elderly population are seen as important determinants of their appearance [9] [10].

There are guidelines for the prevention of PU, which is based on the knowledge and application of relatively simple steps and can be used universally. However, it demands time and attention [11]. 
Meanwhile, the longevity process, vulnerability to morbidity and the emergence of PU are conjugated as factors that hinder the healthy aging and wellbeing may result in worsening of the bio-psychosocial framework of this population, in view of the complex situation generated by institutionalization.

Thus, it is aimed to analyze the association of socio-demographic and clinical characteristics, risk factors and the occurrence of pressure ulcers in institutionalized elderly population.

\section{Method}

It is a cross-sectional and analytical study with a quantitative approach, performed from the database analysis linked to the project "Pressure Ulcer in institutionalized elderly people: Association of incidence with the risk factors to functional and nutritional assessment" developed in six long-stay institutions for the elderly in João Pessoa, registered in the Elderly Population Council of Paraiba, Brazil.

For database all 324 elderly participants of the survey were selected, residents in the period from January to December 2013. Physical examination was carried out of the participants, followed by interview and direct observation of the health condition of the elderly person, and the use of the chart as a secondary source. The risk and the presence of pressure ulcers were evaluated by examining the skin of older people.

For the selection of the subjects, we used as inclusion criteria the elderly people who are 60 years-old or more, residing in the institution, agreeing to participate in the study (those who did not have the physical and/or cognitive conditions to consent to their participation, this was provided by their responsible). As exclusion criteria we consider the elderly who, after interview, died or were absent from the institution due to hospitalization.

Data were analyzed using the Statistical Package for Social Sciences (SPSS) version 20.0. It was initially performed an exploratory analysis of data for characterization of the research subjects using descriptive statistics related to the variables considered in the study. Socio-demographic variables and clinical conditions were associated with the event of interest (pressure ulcers), using the chi square and odds ratio tests with Confidence level of $95 \%$, margin of error related to the considered estimate of $5 \%$.

The Ethics Committee of the Federal University of Paraíba UFPB under Protocol 0468/12 and CAAE, approved the study: 02043712.4.0000.5188. In accordance with the ethical principles of Resolution CNS 466/12 [12], after being informed about the research objectives and voluntary participation, all elders signed (or left the digital brand) the Consent and Informed.

\section{Results}

The statistical analysis of the socio-demographic data showed that from the 324 elderly patients, $75.3 \%$ (244) are the female and $24.7 \%$ (80) are male. In relation to age, the minimum was 60 and the maximum of 109 years-old, the average age 
among the elderly people is 81.17 -year-old $( \pm 9.38)$. As to education, $54.0 \%$ (175) are illiterate or literate, followed by $23.5 \%$ (76) from the elderly people who completed elementary or incomplete primary education, $51.9 \%$ (168) are single, $45.7 \%$ (148) do not have children and 23.6\% (76) had 1or 2 children (Table 1).

Table 1. Socio-demographic profile of the elderly people who live in ILPIs. João Pessoa, $\mathrm{PB}$, Brazil, in 2013.

\begin{tabular}{|c|c|c|}
\hline Socio-Demographic Variables & $\mathrm{N}$ & $\%$ \\
\hline \multicolumn{3}{|l|}{ Age group } \\
\hline $60-70$ & 36 & 11.1 \\
\hline $70-80$ & 100 & 30.9 \\
\hline $80-90$ & 128 & 39.5 \\
\hline $90-100$ & 51 & 15.7 \\
\hline$\geq 100$ & 9 & 2.8 \\
\hline \multicolumn{3}{|l|}{ Sex } \\
\hline Male & 80 & 24.7 \\
\hline Female & 244 & 75.3 \\
\hline \multicolumn{3}{|l|}{ Education } \\
\hline Illiterate or literate & 175 & 54.0 \\
\hline Complete/incomplete primary/elementary education & 76 & 23.5 \\
\hline Complete/incomplete high school & 33 & 10.2 \\
\hline College & 18 & 5.6 \\
\hline NS/NR & 22 & 6.8 \\
\hline \multicolumn{3}{|l|}{ Marital status } \\
\hline Single & 168 & 51.9 \\
\hline Married & 23 & 7.1 \\
\hline Widower & 93 & 28.7 \\
\hline Others $^{1}$ & 40 & 12.3 \\
\hline \multicolumn{3}{|l|}{ Children } \\
\hline No one & 148 & 45.7 \\
\hline $1-2$ & 76 & 23.6 \\
\hline $3-4$ & 31 & 9.5 \\
\hline$>5$ & 23 & 7.0 \\
\hline NS/NR & 46 & 14.2 \\
\hline \multicolumn{3}{|l|}{ Time of institutionalization } \\
\hline$<5$ years & 192 & 59.3 \\
\hline $5-10$ years & 85 & 26.2 \\
\hline$\geq 10$ years & 47 & 14.5 \\
\hline \multicolumn{3}{|l|}{ Income } \\
\hline Retirement & 289 & 89.2 \\
\hline Pension & 14 & 4.3 \\
\hline Others $^{2}$ & 21 & 6.5 \\
\hline Total & 324 & 100 \\
\hline
\end{tabular}

${ }^{1}$ It refers to stable union, divorced, separated and do not know/ did not answer. ${ }^{2}$ It refers to donation, others and do not know/did not answer. 
As for institutionalization time, 59.3\% (192) have been in the institution for less than 5 years and $89.2 \%$ (289) had a monthly income from retirement (Table 1).

In Table 2 we can see that there was not statistically significant association of socio-demographic variables and the related variable to the occurrence of ulcers, as shown by the p-values associated with the respective tests (chi square), odds ratio (odds ratio) and confidence interval (IC).

The analysis of the clinical conditions and the development of pressure ulcers among the institutionalized elderly people, revealed a statistically significant association between the independent variables, neurological disease and change in vision, such as the occurrence of the injury. This association can be seen from the results in Table 3.

Among the risk factors for pressure ulcers, the variables urinary and fecal incontinence, cognitive impairment and physical limitations were significantly associated with the occurrence of PU, with p-value $<0.05$ (Table 4).

Table 2. Associations of socio-demographic variables with the occurrence of pressure ulcers (PU) in institutionalized elderly people-Joao Pessoa, PB, Brazil, in 2013.

\begin{tabular}{cccc}
\hline Variable & p-value & Odds ratio & IC \\
\hline Sex & 0.783 & 0.881 & $0.356-2.179$ \\
Age & 0.744 & 0.874 & $0.388-1.965$ \\
Education & 0.202 & 0.395 & $0.090-1.729$ \\
Marital Status & 0.962 & 1.038 & $0.231-4.669$ \\
Family Income & 0.881 & 0.774 & $0.094-6.371$ \\
Time of institutionalization & 0.105 & 0.444 & $0.163-1.212$ \\
\hline
\end{tabular}

${ }^{\star}$ Statistically significant association $\mathrm{p} \leq 0.05$ (chi square). $\mathrm{CI}=$ confidence interval for odds ratio.

Table 3. Association between clinical conditions and the occurrence of pressure ulcers (PU) among institutionalized elderly population-Joao Pessoa, PB, Brazil, in 2013.

\begin{tabular}{cccc}
\hline Variables & p-value & Odds ratio & IC \\
\hline Osteoarticular diseases & 0.205 & 1.756 & $0.788-4.231$ \\
Cancer & 0.369 & 0.917 & $0.888-0.948$ \\
Diabetes & 0.576 & 1.295 & $0.522-3.213$ \\
Stroke & 0.230 & 1.743 & $0.697-4.359$ \\
Heart disease & 0.388 & 0.418 & $0.054-3.215$ \\
Peripheral Vascular Disease & 0.361 & 1.807 & $0.499-6.536$ \\
Neurological Disease & $0.011^{*}$ & 3.044 & $1.242-7.457$ \\
Hypertension & 1.000 & 1.000 & $0.449-2.229$ \\
Obesity or thinness & 0.157 & 3.021 & $0.607-15.029$ \\
Paralysis & 0.207 & 2.676 & $0.547-13.092$ \\
Change in vision & $0.005^{*}$ & 0.095 & $0.013-0.715$ \\
Change in audition & 0.505 & 0.606 & $0.138-2.675$ \\
Respiratory diseases & 0.737 & 1.296 & $0.284-5.922$ \\
\hline
\end{tabular}

${ }^{\star}$ Statistically significant association $\mathrm{p} \leq 0.05$ (chi square). CI $=$ confidence interval for odds ratio. 
Table 4. Association between risk factors and the occurrence of pressure ulcers (PU) among institutionalized elderly population-Joao Pessoa, PB, Brazil, in 2013.

\begin{tabular}{cccc}
\hline Variables & p-value & Odds ratio & IC \\
\hline Smoking & 0.908 & 1.060 & $0.391-2.877$ \\
Alcohol consumption & 0.571 & 1.371 & $0.459-4.097$ \\
Edema & 0.443 & 1.492 & $0.533-4.178$ \\
Cleanse the skin & 0.550 & 0.918 & $0.888-0.949$ \\
Fractures & 0.744 & 0.844 & $0.304-2.344$ \\
Fecal incontinence & $<0.001^{*}$ & 8.316 & $3.046-22.707$ \\
Urinary incontinence & $<0.001^{*}$ & 14.884 & $3.456-64.134$ \\
Diaper use & 0.364 & 2.765 & $3.943-10.521$ \\
Cognitive deficit & $0.007^{*}$ & 3.672 & $1.349-9.996$ \\
Physical limitation & $<0.001^{*}$ & 9.805 & $2.276-42.238$ \\
\hline
\end{tabular}

*Statistically significant association $\mathrm{p}<0.05$ (chi-square). $\mathrm{CI}=$ confidence interval for odds ratio.

\section{Discussion}

In this study, it is possible to observe the profile of the resident population in long-term institutions in the municipality of João Pessoa (Table 1).There was not any socio-demographic variable that showed a statistically significant association with the occurrence of PU. All Odds ratio values were below 1, except for marital status, which showed slightly higher (1.038), indicating that the sociodemographic variables do not affect the chance of institutionalized elderly subjects for presenting pressure ulcers (Table 2).

However, the results of research carried out in three cities in Brazil evidenced by logistic regression analysis $(r=0.311)$ that the female was predictive of the prevalence of PU in elderly people of LTCI [13]. This reveals that the demands and local conditions may influence differently the risk of injuries.

Despite the variety of studies about PU in the world, they focus their attention mainly in hospital environment [14] [15] [16]. In this scenario, a study of prospective cohort of 534 patients in large hospital in Brisbane, Australia, has identified older age as a factor associated with the development of PU [17]. It should be emphasized that advancing age contributes to the emergence of diseases and worsening health conditions, giving rise to hospitalization.

More recently, researches for elderly people have been conducted in LTCI, analyzing, among other things, the association of socio-demographic characteristics to the development of PU [7] [18]. At this juncture, a study of prevalence of cross-sectional, conducted with 365 institutionalized elderly people in São Paulo, found that there were not significant differences in demographic and clinical characteristics of elderly patients with pressure ulcers for each month of data collection [18].

In LTCI, among the institutionalized elderly patients, there are different clinical conditions, those who remain with their independence for self-care, and those who are partially dependent, or require someone to perform some activity, 
dependent and bedridden. These different general health conditions are not committed to the point of determining hospitalization, which may explain the fact that age is not a factor associated with the development of PU because parallel there is moderate impairment or serious of much of the health status of elderly patients surveyed.

In Table 3, it is observed that the clinical conditions that showed statistically significant associations with the occurrence of pressure ulcers were the variables neurological disorders $(\mathrm{p}=0.011)$ and visual impairment $(\mathrm{p}=0.005)$. About the odds ratio, the value of odds ratio was 3044 to neurological disease. This means that elderly patients who are residents in LTCI with this type of clinical impairment don't have chance to present PU three times higher than those without neurological disease. The confidence interval for this variable showed minimum value above 1 , confirming the significance and the chance of this group in presenting PU (Table 3).

It is known that neurological disease predisposes to increased length of stay in bed. The data corroborate similar research in which there was a significant association between neurological disease and PU [8]. According to the findings, studies that tested strategies for reduction of PU in hospital say that people with neurological injuries or alterations have great chance to present such chronic wounds [19] [20]. Thus, these findings support the evidence for relationship between neurological and emergence of PU.

Although the variable vision changes have presented significant $(\mathrm{p}=0.05)$, the odds ratio was 0.095 i.e., it is considered as a protective factor in this study population. It is believed that institutionalized elderly patients associated with this clinical impairment need special care professionals and caregivers due to loss of autonomy in performing daily tasks. It is understood that the preventive measures are intensified reducing the chance of involvement of the injury.

It is noteworthy that although there was not significant association between obesity or thinness with $\mathrm{PU}$, the odds ratio $(\mathrm{OR}=3.021)$ provided evidence that the elders in these clinical conditions have three times more likely to develop the injury, compared to those with normal weight. In this line of reasoning, it can be said that the data provided evidence that the high weight increases the pressure on the contact surface, whereas low weight exacerbates the pressure on bony prominences. So, both of them can negatively influence blood flow in the skin compression areas, causing PU.

In addition, poor nutritional status constitutes a risk factor for the advent of the PU, due to the reduction of oxygen, which reduces tissue tolerance to pressure. The PU progress rapidly and are more resistant to treatment in patients with nutritional disorders, complicating the healing process and increasing the susceptibility to complications. In people with malnutrition, specific therapy for the treatment of pressure ulcers is precisely indicated by the difficulty of production of fibroblasts, neoangiogenesis and collagen synthesis, and less tissue restoration capacity [21].

Meanwhile, clinical evaluation is initially recommended in order to examine 
changes in body composition, poor dietary intake, changes the organism by functional modification as well as the use of therapies composed by immunemodulators and higher protein content of nutrients to accelerate the process of healing the lesion [22] [23].

Another risk factor associated with the PU is the prolonged stay in the same position [24]. Study found that individuals with higher amounts of fat have more chance of initial protection against PU, compared to those with less fat, although both develop injury when are not mobilized properly. Therefore, the reduced fat may facilitate the occurrence of the wound more quickly [25].

Thus, it is understood that in the aging process the adipose tissue and body mass due to the nutritional status to vulnerability to PU, especially among the elderly who is bedridden due to bed rest, pressure on bony prominences and other associated medical conditions.

In addition to therapeutic products, the literature states that the most interesting strategies for PU prevention are directed to postural change or change of placement, special mattress or use pillows to ease the pressure and education to patients and caregivers. These alternatives together reduce greatly the tissue damage and increases survival [25] [26].

With regard to risk factors, fecal incontinence $(\mathrm{p}<0.001)$, urinary incontinence ( $\mathrm{p}<0.001)$, cognitive impairment $(\mathrm{p}=0.007)$ and physical limitation $(\mathrm{p}<$ 0.001) showed statistically significant associations for the occurrence of PU. It was also showed that elderly people with physical limitations have odds ratio nine times greater for the occurrence of $P U(O R=9.805)$, with confidence interval (CI) between 2.276 to 42.238 , compared to those with preserved mobility.

Cognitive impairment and physical limitations are conditions that enhance the patient's exposure to moisture, by urine, sweat or feces, accelerating the process of appearance of the lesion. Excessive moisture influences the change of the skin resistance generating serious consequences to elders' health, predisposing maceration and friction, making it easily susceptible to risk of developing UP [10]. In addition to the impact on the integrity of the skin, loss of bladder and bowel control can result in embarrassment and consequent social isolation.

It is necessary to point out that the municipality where the research has been developed has hot climate feature. In addition, the institutions do not have sufficient financial resources to acquire fans and cooled air, devices that reduce the production of sweat and promote comfort for the elders. In this sense, the environment becomes favoring moisture and change in the skin, being indicated for use as protective barrier creams and achieving proper hygiene [27].

Some risk factors such as smoking, alcohol consumption, skin cleansing and the use of diapers were evaluated in order to verify association with the occurrence of PU. However, none of them showed a statistically significant association, although it appeared interesting result for odds ratio (odds ratio) related to the use of diapers (2765). This means that the institutionalized elderly people in diaper use have almost three times higher chance for occurrence of PU when compared to those who do not use. 
It is known that the lack of autonomy and dependence of this clientele requires from professionals the need for daily care, which requires specific knowledge and techniques in order to contribute to minimizing the risks to this grievance. Still, there are few studies of the long-term institutions that portray the practice of daily actions as preventive measures.

Recent data show that the PU reduction in US hospitals is related to the implementation of evidence-based practices. Among the aforementioned factors, the availability of specialized nurses in PU and care protocols was priorities for injury prevention [28]. Thus, routines and behaviors outlined for the specific care of pressure ulcers should be encouraged, especially among professionals who work in LTCI due to considerable occurrence of these injuries.

This study highlights the individual clinical characteristics of the elderly people, which are factors that act synergistically and predispose to the development of the lesion. Therefore, there is a need for professionals and caregivers to assure the quality of assistance in the prevention of pressure ulcers.

For this, just as there is an urgent need to develop care protocols, it is also important to use Scales as an instrument to facilitate the identification of risks to the development of the lesion. In addition, skin inspection and the application of protective devices for pressure relief at sites of bone prominence represent practices that will allow early detection of risk and prevention of injury.

So, despite the work overload in LTCI, nursing should pay attention to risk reduction and prevention of PU in institutionalized elderly patients, especially when they are flagged factors such as neurological problems, use of the presence of wheelchairs or bedridden, malnutrition and related clinical manifestations the occurrence of injury.

Thus, the elderly people inserted in this context require that professionals of all levels of knowledge seek intervention measures, with a view to changing attitudes related to the management of technical and essential therapeutic approaches to improve the quality of life and reduce the onerous costs demanded to health, since the institutions are philanthropic and lack of wealthy financial resources.

\section{Conclusions}

In this study, there was not statistically significant association between socio-demographic characteristics and the occurrence of PU. However, significant results were found for the variables neurological disease, abnormal vision, urinary incontinence, fecal incontinence, cognitive impairment and physical limitations. Moreover, the odds ratio for the occurrence of the injury was nine times higher for elders with physical limitations and about three times higher among those who use diapers.

Analysis of associations of risk factors observed in this study demonstrates the importance of the study, since relented to the scenarios studied problems that require intervention to prevent health implications of the elders and minimize the risk and occurrence of PU. In this sense, it is necessary for institutions to 
provide quantitative adequate professionals to meet the demand of the local, as well as the participation of nurses, nursing technicians and caregivers in training to promote strategies and quality management in this service

Additionally, it reflects on the need to implement service and systematized record of protocols, which is aimed at preventing and or decreasing this complication, promoting the independence and autonomy of the elders for longer.

However, we see the need to meet various realities, whether hospital, outpatient or home, for the nursing practice has scientific basis. So, it emphasizes the convenience of publications whose study locus is LTCI so that the procedures developed by nurses are more specific and resolute

\section{References}

[1] Sousa, K.T., Mesquita, L.A.S., Pereira, L.A. and Azeredo, C.M. (2014) Baixo peso e dependência funcional em idosos institucionalizados de Uberlândia (MG), Brasil. Revista Ciência \& Saúde Coletiva, 19, 3513-3520. http://www.scielo.br/pdf/csc/v19n8/1413-8123-csc-19-08-03513.pdf

[2] Menezes, R.L., Bachion, M.M., Souza, J.T. and Nakatani, A.Y.K. (2011) Estudo longitudinal dos aspectos multidimensionais da saúde de idosos institucionalizados. Revista Brasileira de Geriatria e Gerontologia, 14, 485-496. http://www.scielo.br/pdf/rbgg/v14n3/v14n3a09

[3] Freitas, M.C., Guedes, M.V.C., Galiza, F.T., Nogueira, J.M. and Onofre, M.R. (2014) Idosos residentes em uma instituição de longa permanência: Adaptação à luz de Callista Roy. Revista Brasileira de Enfermagem, 67, 905-912. http://www.scielo.br/pdf/reben/v67n6/0034-7167-reben-67-06-0905.pdf

[4] Oliveira, P.B. and Tavares, D.M.S. (2014) Condições de saúde de idosos residentes em Instituição de Longa Permanência segundo necessidades humanas básicas.. Revista Brasileira de Enfermagem, 67, 241-246. http://www.scielo.br/pdf/reben/v67n2/0034-7167-reben-67-02-0241.pdf

[5] Camarano, A.A. and Kanso, S. (2011) Previdência Social no Brasil: Contornos e horizontes. Previdência Social no Brasil: Contornos e horizontes. In: Biasoto Junior, G. and Silva, L.A.P., Políticas Públicas em questão, São Paulo, 27-57.

[6] da Saúde, M. and de Vigilância Sanitária, A.N. (2005) RDC nº 283, de 26 de setembro de 2005. Regulamento técnico para o funcionamento das instituições de longa permanência para idosos. Brasília.

[7] Freitas, M.C., Medeiros, A.B.F., Guedes, M.V.C., Almeida, P.C., Galiza, F.T. and Nogueira, J.M. (2011) Úlcera por pressão em idosos institucionalizados: Análise da prevalência e fatores de risco. Revista Gaúcha de Enfermagem, 32, 143-150.

[8] Aguiar, E.S.S., Soares, M.J.G.O., Caliri, M.H.L., Costa, M.M.L. and Oliveira, S.H.S. (2012) Evaluación de la capacidad funcional de ancianos asociada al riesgo de úlcera por presión. Acta Paulista de Enfermagem, 25, 94-100. http://www.redalyc.org/pdf/3070/307026828015.pdf

[9] National Pressure Ulcer Advisory Panel, European Pressure Ulcer Advisory Panel and Pan Pacific Pressure Injury Alliance (2014) Prevention and Treatment of Pressure Ulcers: Quick Reference Guide. Haesler, E., Ed., Cambridge Media, Osborne Park, Western Australia.

[10] Domansky, R.C. and Borges, E.L. (2012) Manual para prevenção de lesões de pele: Recomendações baseadas em evidências. Rubio, Rio de Janeiro.

[11] Ministério da Saúde, Agência Nacional de Vigilância Sanitária (BR) (2013) Portaria 
No. 2.095, de 24 de setembro de 2013: Aprova os Protocolos Básicos de Segurança do Paciente, Brasília.

http://bvsms.saude.gov.br/bvs/saudelegis/gm/2013/prt2095_24_09_2013.html

[12] Ministério da Saúde, Conselho Nacional de Saúde, Comissão Nacional de ética em Pesquisa (Br) (1996) Normas para pesquisa envolvendo seres humanos: (Res. CNS 196/96 outras). Brasília.

[13] Souza, D.M.S.T. and Santos, V.L.C.G. (2007) Fatores de risco para o desenvolvimento de úlceras por pressão em idosos institucionalizados. Revista Latino-Americana de Enfermagem, 15, 958-964. http://www.scielo.br/pdf/rlae/v15n5/pt_v15n5a11.pdf https://doi.org/10.1590/S0104-11692007000500012

[14] Gedamu, H., Hailu, M. and Amano, A. (2014) Prevalence and Associated Factors of Pressure Ulcer among Hospitalized Patients at Felegehiwot Referral Hospital, Bahir Dar, Ethiopia. Advances in Nursing, 2014, Article ID: 767358.

https://doi.org/10.1155/2014/767358

[15] Banks, M.D., Graves, N., Bauer, J.D. and Ash, S. (2013) Cost Effectiveness of Nutrition Support in the Prevention of Pressure Ulcer in Hospitals. European Journal of Clinical Nutrition, 67, 42-46. https://doi.org/10.1038/ejcn.2012.140

[16] Sving, E., Gunningberg, L., Hogman, M. and Mamhidir, A.G. (2012) Registered Nurses' Attention to and Perceptions of Pressure Ulcer Prevention in Hospital Settings. Journal of Clinical Nursing, 21, 1293-1303. https://doi.org/10.1111/j.1365-2702.2011.04000.x

[17] Webster, J., Lister, C., Corry, J., Holland, M., Coleman, K. and Marquart, L. (2015) Incidence and Risk Factors for Surgically Acquired Pressure Ulcers: A Prospective Cohort Study. Investigators, 42, 138-144. https://doi.org/10.1097/won.0000000000000092

[18] Chacon, J.M.F., Blanes, L., Hochman, B. and Ferreira, L.M. (2009) Prevalence of Pressure Ulcers among the Elderly Living in Long-Stay Institutions in São Paulo. Sao Paulo Medical Journal, 127, 211-215. http://www.scielo.br/pdf/spmj/v127n4/v127n4a06.pdf https://doi.org/10.1590/S1516-31802009000400006

[19] Bauman, W.A., Spungen, A.M., Collins, J.F., Raisch, D.W., Ho, C., Deitrick, G.A., Nemchausky, B.A., Goetz, L.L., Park, J.S., Schwartz, M., Merritt, J.L., Jayawardena, V., Sandford, P., Sabharwal, S., Holmes, S.A., Nasar, F., Sasaki, R., Punj, V., Zachow, K.F., Chua, W.C., Thomas, M.D. and Trincher, R.C. (2013) The Effect of Oxandrolone on the Healing of Chronic Pressure Ulcers in Persons with Spinal Cord Injury: A Randomized Trial. Annals of Internal Medicine, 158, 718-726.

http://www.ncbi.nlm.nih.gov/pubmed/23689765 https://doi.org/10.7326/0003-4819-158-10-201305210-00006

[20] Nussbaum, E.L., Flett, H., Hitzig, S.L., McGillivray, C., Leber, D., Morris, H. and Jing, F. (2013) Ultraviolet-C Irradiation in the Management of Pressure Ulcers in People with Spinal Cord Injury: A Randomized, Placebo-Controlled Trial. Archives of Physical Medicine and Rehabilitation, 94, 650-659.

http://www.archives-pmr.org/article/S0003-9993(12)01213-0/pdf https://doi.org/10.1016/j.apmr.2012.12.003

[21] Correia, M.I.T.D., Renofio, J., Serpa, L., Rezende, R. and Passos, R.M. (2011) Terapia Nutricional para Portadores de Úlceras por Pressão. Projeto Diretrizes. Associação Médica Brasileira e Conselho Federal de Medicina.

[22] Lee, S.K., Posthauer, M.E., Dorner, B., Redovian, V. and Maloney, M. (2006) Pressure Ulcer Healing with a Concentrated, Fortified, Collagen Protein Hydrolysate Supplement: A Randomized Controlled Trial. Advances in Skin \& Wound Care, 19, 
92-96. https://doi.org/10.1097/00129334-200603000-00011

[23] Thomas, D.R. (2014) Role of Nutrition in the Treatment and Prevention of Pressure Ulcers. Nutrition in Clinical Practice, 29, 466-472.

http://ncp.sagepub.com.ez15.periodicos.capes.gov.br/content/29/4/ https://doi.org/10.1177/0884533614539016

[24] Biglari, B., Büchler, A., Reitzel, T., Swing, T., Gerner, H.J., Ferbert, T. and Moghaddam A. (2014) A Retrospective Study on Flap Complications after Pressure Ulcer Surgery in Spinal Cord-Injured Patients. Spinal Cord, 52, 80-83.

http://www.ncbi.nlm.nih.gov/pubmed/24216618 https://doi.org/10.1038/sc.2013.130

[25] Bhattacharya, S. and Mishra, R.K. (2015) Pressure Ulcers: Current Understanding and Newer Modalities of Treatment. Indian Journal of Plastic Surgery, 48, 4-16.

http://www.ncbi.nlm.nih.gov/pmc/articles/PMC4413488/ https://doi.org/10.4103/0970-0358.155260

[26] Agrawal, A. and Chauhan, N. (2012) Pressure Ulcers: Back to the Basics. Indian Journal of Plastic Surgery, 45, 244-254. https://doi.org/10.4103/0970-0358.101287 http://www.ncbi.nlm.nih.gov/pmc/articles/PMC3495374/

[27] Luz, R.P., Lopacinski, A.C., Fraga, R. and Urban CA. (2010) Úlceras de pressão. Geriatrgerontol, 4, 36-43.

[28] Padula, W.V., Valuck, R.J., Makic, M.B.F. and Wald, H.L. (2015) Factors Influencing Adoption of Hospital-Acquired Pressure Ulcer Prevention Programs in US Academic Medical Centers. Journal of Wound Ostomy \& Continence Nursing, 42, 327-330. https://doi.org/10.1097/WON.0000000000000145 http://journals.lww.com/jwocnonline/Abstract/2015/07000/Factors_Influencing_Ad option_of_Hospital_Acquired.3.aspx

\section{Submit or recommend next manuscript to SCIRP and we will provide best service for you:}

Accepting pre-submission inquiries through Email, Facebook, LinkedIn, Twitter, etc. A wide selection of journals (inclusive of 9 subjects, more than 200 journals)

Providing 24-hour high-quality service

User-friendly online submission system

Fair and swift peer-review system

Efficient typesetting and proofreading procedure

Display of the result of downloads and visits, as well as the number of cited articles

Maximum dissemination of your research work

Submit your manuscript at: http://papersubmission.scirp.org/

Or contact ojn@scirp.org 